\title{
Ensino de língua estrangeira em contexto digital: uma nova oportunidade de aprendizado para professores e alunos
}

\author{
Adriana Maria Ramos Oliveira ${ }^{\mathrm{i}}$ \\ Entrevistadoras: \\ Evânia Maria Ferreira do Nascimento ${ }^{\text {ii }}$ \\ Gabriela Ribeiro Nunes ${ }^{\text {iii }}$ \\ Marcela Santos Brigida ${ }^{\text {iv }}$
}

O ano de 2020 vai ficar na lembrança de todos aqueles que sobreviverem a ele. A afirmativa tem um tom mórbido, mas não poderia deixar de ser assim, em virtude da contabilização de milhares de mortos, vítimas da Covid-19. À época da escrita deste trabalho, já eram computadas mais de cento e setenta mil mortes em virtude da doença. De alguma forma, nos lembraremos do ano de 2020 por muito tempo; seja pela proximidade a que a morte nos chegou ao atingir um parente ou amigo, seja pelas novas formas de ser que se fizeram necessárias: intensificação da higienização geral, uso de

\footnotetext{
${ }^{\text {i }}$ Possui graduação e licenciatura em Letras (Português-Espanhol) pela Universidade Federal do Rio de Janeiro (1996), especialização como professora de Lengua y Literaturas Españolas pela Agencia Española de Cooperación Internacional - AECI (1997), mestrado em Letras Neolatinas pela Universidade Federal do Rio de Janeiro (2000), magíster em Alta Especialización en Filología Hispánica pelo Consejo Superior de Investigaciones Científicas - CSIC (2002), Doutorado em Língua Espanhola e Linguística Aplicada UNED (2002) e Doutorado em Estudos da Linguagem - UFF (2019). É professora colaboradora nos cursos de Pós-Graduação da Universidade Estácio de Sá, professora do Instituto Cervantes e professora do Ensino Básico Técnico e Tecnológico do Centro Federal de Educação Tecnológica Celso Suckow da Fonseca - CEFET/RJ no Bacharelado em Línguas Estrangeiras Aplicadas às Negociações Internacionais (LEANI). Coordena o LEANI TRAD (Laboratório de Tradução do Bacharelado em LEANI) e tem experiência na área de Letras, com ênfase em Línguas Estrangeiras Modernas (Espanhol), Formação de Professores, Tradução e Novas Tecnologias Aplicadas ao Ensino de Idiomas.

adriana.oliveira@cefet-rj.br
}

\footnotetext{
ii Professora efetiva do Instituto Federal Fluminense, campus Santo Antônio de Pádua, e doutoranda em Linguística no Programa de Pós-Graduação em Letras da UERJ. Atua com ensino de língua portuguesa, literatura brasileira e língua espanhola e, atualmente, seu interesse de pesquisa está voltado para a análise de materiais didáticos e para as políticas linguísticas para ensino do espanhol no Brasil. evaniamariaferreira33@gmail.com

iii Doutoranda em Teoria da Literatura/Literatura Comparada pela Universidade do Estado do Rio de Janeiro (UERJ). j15c17g11@hotmail.com

iv Doutoranda em Estudos Literários na Universidade do Estado do Rio de Janeiro (UERJ). Bolsista CNPq. marcela.brigida@uerj.br
} 
máscara facial e... o tão doloroso distanciamento físico, que alterou, principalmente, a rotina daqueles envolvidos em atividades que preveem aglomeração de pessoas. E a atividade escolar é uma delas.

Em obediência às medidas de prevenção à disseminação do novo Coronavírus, as escolas permaneceram fechadas durante muito tempo e, para tentar dar continuidade ao processo de ensino e aprendizagem, submetemo-nos ao ensino remoto, cujo distanciamento entre professor e aluno dá lugar a uma de suas principais características: a interação (quando há) mediada pelo uso das novas tecnologias. Agora, aluno e professor não partilham do mesmo espaço e tempo no processo de aprendizagem.

Tendo em vista esta nova realidade que estamos enfrentando como profissionais da educação, convidamos a professora Adriana Maria Ramos Oliveira para compartilhar suas experiências e conhecimentos sobre o assunto. Graduada em Letras (PortuguêsEspanhol) pela Universidade Federal do Rio de Janeiro (1996), possui especialização como professora de Lengua y Literaturas Españolas pela Agencia Española de Cooperación Internacional - AECI (1997), mestrado em Letras Neolatinas pela Universidade Federal do Rio de Janeiro (2000), magíster em Alta Especialización en Filología Hispánica pelo Consejo Superior de Investigaciones Científicas - CSIC (2002), doutorado em Língua Espanhola e Linguística Aplicada - UNED (2002) e doutorado em Estudos da Linguagem - UFF (2019). É professora colaboradora nos cursos de Pós-Graduação da Universidade Estácio de Sá, do Instituto Cervantes e do Ensino Básico Técnico e Tecnológico do Centro Federal de Educação Tecnológica Celso Suckow da Fonseca - CEFET/RJ no Bacharelado em Línguas Estrangeiras Aplicadas às Negociações Internacionais (LEANI). Tem experiência na área de Letras, com ênfase em Línguas Estrangeiras Modernas (Espanhol), Formação de Professores, Tradução e Novas Tecnologias Aplicadas ao Ensino de Idiomas.

Ficamos muito gratas com o aceite da professora Adriana, que nos mostrou que a experiência do ensino de línguas à distância mediado pelas ferramentas digitais, apesar de ser um desafio para aqueles que não estão acostumados a usá-las, não compromete a qualidade do aprendizado. Pelo contrário, podem torná-la ainda mais enriquecedora. A mensagem que ela nos deixa resume bem o trabalho do docente. É um convite para que não nos deixemos desanimar e aproveitemos as oportunidades que este novo paradigma nos trouxe, a fim de nos tornarmos "os professores que os nossos 
alunos precisam nos diferentes momentos da vida e fases de aprendizagem". Não estávamos preparados para esta realidade, mas a professora Adriana nos mostrou a importância de aceitarmos os desafios com todos os contratempos possíveis de se prever. Tenham todos e todas uma boa leitura, aproveitando o conhecimento que nossa entrevistada gentilmente compartilhou com a revista Palimpsesto e nossos leitores.

\section{PALIMPSESTO}

1) No contexto do ensino mediado pelas tecnologias no ensino remoto, fomentado em virtude da pandemia do novo Coronavírus, ficou mais fácil ensinar línguas estrangeiras? É possível ampliar mais os conteúdos e temas a serem trabalhados ou ficará ainda mais difícil para o professor selecioná-los?

\section{ADRIANA MARIA RAMOS OLIVEIRA}

Não necessariamente. Vai depender do docente porque as tecnologias já existiam antes da pandemia, mas nem todos os docentes a utilizavam. Se pensarmos que o ensino de uma língua estrangeira sempre foi reduzido nas escolas e vermos as tecnologias como uma forma de expandir o espaço físico da sala de aula, podemos ampliar o número de horas que os nossos alunos têm em contato com a língua. Mas eu sempre digo que o mais importante é levar para a sala de aula - física ou virtual - só aquela tecnologia que realmente vá ajudar à labor docente, porque não adianta usar tecnologia com a qual não se está acostumado e que suponha uma dificuldade a mais para o aluno. Ou seja, além de aprender a língua estrangeira, também terá que aprender a lidar com uma ferramenta que pode ser desconhecida para ele só porque o professor acha que deve usá-la, por exemplo. Além disso, não podemos nos esquecer que "tecnologia" não são só os aparelhos modernos de que dispomos ou a internet. Também era tecnologia a pintura nas cavernas, a invenção do papel ou a criação da imprensa nas suas respectivas épocas.

\section{PALIMPSESTO}


2) Com o isolamento social e o ensino remoto, muitas escolas foram obrigadas a adotar plataformas digitais para prosseguirem o ano letivo. Entretanto, muitos professores, apesar de estarem inseridos em um novo contexto (o digital), insistem em lecionarem a matéria praticamente da mesma maneira que presencialmente. Sendo pesquisadora da área, como os docentes podem incorporar plenamente as ferramentas digitais no ensino de línguas estrangeiras? Como usá-las também em uma realidade presencial póspandemia?

\section{ADRIANA MARIA RAMOS OLIVEIRA}

É preciso que haja uma formação ampla na área digital para que os docentes vejam a tecnologia de uma forma mais ampla. Não basta fazer um Power Point e projetá-lo no Datashow para dizer que está incorporando uma ferramenta digital. Por exemplo, dependendo da atividade que queiramos desenvolver (enquanto professores), podemos usar o Powtoon (https://www.powtoon.com) para oferecer instruções aos alunos; criar um mapa de trabalho com Canva (https://www.canva.com/); realizar uma galeria de avatares de personagens com Voki (https://www.voki.com/); dar uma série de pistas para a solução de um mistério usando Genially (https://app.genial.ly/); procurar imagens representativas em Pixabay (https://pixabay.com/es/), gamificar um conteúdo com Kahoot (https://kahoot.com/schools-u/) etc. Tendo em mente a possibilidade de expandir, com as novas tecnologias, o tempo da aula muito além do espaço físico, nada melhor do que usar a tecnologia a nosso favor e desenvolver as habilidades dos nossos alunos mesmo que de forma remota e com o benefício de uma maior inclusão e respeito ao ritmo de cada um, tendo em conta, principalmente, que o mais importante é só levar as ferramentas que nos ajudem na nossa prática docente, para que isso não suponha um problema maior tanto para nós como docentes, quanto para os nossos alunos.

Antes mesmo do surgimento da pandemia, eu já acreditava e defendia que as faculdades de formação de professores incluíssem uma disciplina voltada para as novas tecnologias, para o desenvolvimento do letramento digital do futuro docente. Ou seja, que fosse possível também formar os novos professores de forma digital e que eles pudessem criar materiais, produzir vídeos didáticos, trabalhar ferramentas multimídia etc. de forma mais prática e simples porque se antes nos ensinavam - nas aulas de didática - a como escrever no quadro, onde nos posicionarmos na sala, metodologias de 
ensino... nesta nova realidade, independentemente da Covid-19, precisamos formar professores com competências digitais também!

\section{PALIMPSESTO}

3) Diante de um aparente conflito revelado na fala resistente de alguns professores da escola básica em não querer utilizar as novas tecnologias, como a escola pode se apropriar das novas linguagens e formas de interação digitais de modo a respeitar as subjetividades de alunos e professores?

\section{ADRIANA MARIA RAMOS OLIVEIRA}

Sempre que eu encontro algum colega resistente a usar as novas tecnologias, eu me lembro de como os garçons anotavam os pedidos uns 10 anos atrás. Se pensarmos que eles anotavam os pedidos em blocos de papel antes e que agora anotam em tablets ou telas interativas, o que aconteceria com o garçom que dissesse ao seu chefe "não vou aprender isso não" ou "quero continuar anotando os pedidos no papel" ou ainda "não sei usar isso"?? Provavelmente seria despedido! Ou seja, se todas as profissões precisaram se adaptar às novas tecnologias em algum momento, por que com os professores seria diferente? Algo que sempre me chamou a atenção com relação à sala de aula é que, apesar de que os anos passam, ela não evolui propriamente. Se pegarmos uma imagem de um dos primeiros celulares e um de agora, veremos que as mudanças são imensas, mas se pegarmos uma foto de uma sala de aula dos anos 50 e uma de agora, veremos que quase não há diferenças...

Por último, recomendo um livro muito útil chamado Mão na massa ${ }^{1}$, no qual os autores fazem uma coletânea de uma série de ferramentas digitais que podem ser incorporadas à sala de aula de línguas estrangeiras.

\section{PALIMPSESTO}

4) A senhora desenvolve um projeto intitulado "Os blogs no ensino do espanhol como língua estrangeira: proposta de uma revista virtual" no qual mostra uma preocupação 
com a chamada "alfabetização digital". No que consiste tal conceito, qual a importância de compreendê-lo e de onde surgiu o interesse pelo tema?

\section{ADRIANA MARIA RAMOS OLIVEIRA}

A proposta deste projeto é trabalhar o uso dos blogs como uma das muitas ferramentas disponíveis na Web 2.0. Tanto alunos quanto professores precisam adaptarse aos novos modelos educativos e isto supõe uma mudança, um novo enfoque e novos métodos que nos aproximem da chamada "alfabetização digital”. A proposta de criação de uma revista digital em língua estrangeira faz com que o uso do blog seja uma ferramenta para a procura, o tratamento e a produção de informação relevante para a aprendizagem dos alunos como um todo. O blog pode proporcionar que o objetivo de uma alfabetização digital seja mais próximo, porque é uma ferramenta que permite apresentar conteúdos de maneira simples e atraente para os discentes. Como o blog permite gerar, publicar e intercambiar conteúdos em múltiplos formatos (vídeo, imagem, áudio) sem a necessidade de contar com uma grande capacidade tecnológica e se relaciona com outros formatos e aplicações da rede como páginas web, marcadores sociais, geradores de conteúdo etc., se converte em uma ferramenta idônea para o trabalho realizado pelos professores de língua estrangeira da instituição, para outros docentes da rede pública e/ou privada do Estado do Rio de Janeiro e para estimular atividades de promoção da língua estrangeira entre os alunos da instituição, em particular, a partir da criação da revista digital. Sendo assim, este projeto teve como objetivo principal apresentar o blog como ferramenta tecnológica no ensino de línguas estrangeiras, em particular o espanhol.

\section{PALIMPSESTO}

5) Como trabalhar nossas responsabilidades cidadãs quando apresentamos o mundo a nossos alunos nas aulas de línguas, por meio de tantas ferramentas digitais disponíveis?

\section{ADRIANA MARIA RAMOS OLIVEIRA}

Volto a dizer que o mais importante, quando levamos qualquer tecnologia à sala de aula, é levar só o que possa facilitar o trabalho docente e, consequentemente, o 
processo de ensino/aprendizagem. Tudo o que representar uma dificuldade/um problema a mais, deve ser evitado. Sendo assim, o professor precisa fazer uma seleção e uma espécie de curadoria das ferramentas que pretende utilizar e tem que ter muito claro quais são os objetivos que ele pretende alcançar com o uso da(s) ferramenta(s) utilizada.

Além disso, Mishra e Koehler (2006, p. 1018) afirmam que apenas introduzir tecnologia ao processo de ensino-aprendizagem não é suficiente. Recentemente, questionamentos sobre o que os professores devem saber para incorporar a tecnologia de forma adequada em suas práticas receberam bastante atenção. Cada vez mais o foco das pesquisas está em como a tecnologia é usada pelos professores. Para os autores, na atualidade os docentes terão sempre de atualizar saberes sobre o uso das Tecnologias Digitais de Informação e Comunicação (TDIC) e incorporá-los às suas práticas.

\section{PALIMPSESTO}

6) Para a senhora, como é possível perpassar as barreiras que o contexto digital impõe na interação entre os alunos quando se trata do ensino de línguas estrangeiras? $\mathrm{O}$ desenvolvimento da oralidade fica afetado?

\section{ADRIANA MARIA RAMOS OLIVEIRA}

Na minha opinião, o contexto digital não impõe nenhuma barreira na interação com os alunos! Continuamos interagindo com eles, mas de maneira diferente. Ao compararmos a interação presencial com a digital, vemos que, na maioria das vezes, a interação digital já é a que os nossos alunos mais usam atualmente. Ou seja, eles interagem muito mais entre eles, com os familiares, com os professores digitalmente do que pessoalmente. É verdade que a nossa cultura é muito mais próxima e afetuosa no que diz respeito à relação professor-aluno, principalmente quando se tratam de crianças pequenas, mas quando estamos falando de jovens ou adultos, a grande maioria vive postando opiniões nas redes sociais, escrevendo mensagens nos apps, dando likes, etc.

Atualmente, as ferramentas utilizadas para o ensino remoto (Microsoft Teams, Zoom, Google Meets, Skype etc.) permitem que haja uma interação síncrona professoraluno ou aluno-aluno. É possível formar duplas, fazer atividades de perguntas e respostas, jogar e qualquer outra atividade que estimule e desenvolva a oralidade. Além 
disso, também podemos gravar vídeos ou áudios de forma a analisar a expressão do aluno de maneira mais detalhada posteriormente e há uma série de outras dinâmicas que não eram possíveis presencialmente e só são possíveis porque estamos em um contexto digital. Por isso, se o professor pesquisar e aprender os recursos da plataforma que estiver utilizando na sua prática docente, pode desenvolver muitas atividades e trabalhar as quatro habilidades digitalmente de maneira, inclusive, mais ampla que se estivesse trabalhando presencialmente. Até porque, se pensarmos que as tecnologias nos ajudam a expandir o espaço físico da sala de aula - não estaremos limitados a 1 tempo de 40/45 minutos, por exemplo - poderemos usar todos estes recursos a nosso favor em prol da aprendizagem dos alunos.

\section{PALIMPSESTO}

7) Como conciliar os diferentes graus de desigualdade social presentes na escola (e também na universidade) no contexto pós-pandemia e os novos tipos de saberes adquiridos/construídos pelos professores?

\section{ADRIANA MARIA RAMOS OLIVEIRA}

Essa pergunta é muito difícil porque extrapola até onde podemos chegar enquanto docentes. Ou seja, antes da pandemia, já lidávamos com a questão da desigualdade social presente nas instituições de ensino de diversas maneiras: colocando um aluno que não tivesse acesso ao material para fazer um exercício com quem tivesse; pagando fotocopias com dinheiro do bolso para distribuir para todos os alunos; mandando textos e atividades por e-mail ou WhatsApp tentando democratizar o máximo possível o acesso, mas sabemos que no contexto pós-pandemia, a desigualdade social, que já era muito grande no nosso país, estará ainda maior... Eu diria que vamos precisar fazer uma espécie de "reconhecimento de terreno" quando a pandemia passar, reencontrar os nossos alunos, ouvi-los, respeitar as necessidades individuais e, a partir do panorama encontrado, fazer o que fazemos sempre: desenhar estratégias que nos permitam levar o conhecimento a todos. A vantagem é que, com os novos tipos de saberes adquiridos/construídos pelos professores, esse desenho pedagógico/metodológico será muito mais fácil porque uma das características das 
novas tecnologias é se adequar ao momento de aprendizagem e às necessidades de cada um.

David Kolb (1984) desenvolveu uma teoria sobre 4 estilos de aprendizagem, na qual afirma que "os adultos têm diferentes maneiras de aprender" e que dependem de como percebem e processam a realidade. Segundo o autor, podemos ser adaptadores, assimiladores, divergentes e convergentes; assim, a informação não é captada da mesma forma por todos já que alguns a processam (ação), enquanto outros refletem sobre o que leem ou observam (pensamento). Sendo assim, na minha opinião, a melhor forma de conciliar a enorme desigualdade social que temos é disponibilizar o material que vamos trabalhar na sala de aula, de várias formas possíveis: um vídeo, um texto, um e-book, uma imagem, um áudio...

\section{PALIMPSESTO}

8) Como aproveitar o conhecimento digital dos estudantes (muitas vezes maior do que o dos professores) nas atividades pedagógicas?

\section{ADRIANA MARIA RAMOS OLIVEIRA}

Muito fácil. O professor precisa entender que a sala de aula, virtual ou não, é uma via de duplo sentido. Ou seja, já não existe mais a figura de que o professor é o detentor de todo o saber, enquanto os alunos são caixinhas vazias que precisem ser preenchidas. Eu, particularmente, costumo dizer que aprendo muito mais com os meus alunos do que eles comigo. Precisamos ver o processo de ensino/aprendizagem como uma troca de saberes. Assim, da mesma forma que eu ensino o meu aluno a conjugar determinado verbo em língua estrangeira, por exemplo, ele pode me ensinar a editar um vídeo.

\section{PALIMPSESTO}

9) Como equilibrar a resistência de alguns estudantes ao uso das plataformas digitais para o ensino remoto com a euforia de outros pelo seu uso, num contexto de heterogeneidade do público atendido? 


\section{ADRIANA MARIA RAMOS OLIVEIRA}

Sinceramente, não vejo que o professor possa fazer muito nesse caso. Na minha experiência, sempre que eu me vi nessa situação, a resistência de poucos estudantes ao uso das plataformas digitais acontecia por desconhecimento da ferramenta em questão, falta de acesso à internet, mas nunca porque tivessem desenvolvido uma aversão total àquela plataforma. Então, em um primeiro momento, procurava dar as informações básicas para que o aluno pudesse, pelo menos começar, entrar em contato com a plataforma, ver que "não seria mordido" e depois fazia pequenos grupos entre resistentes e eufóricos para que entre eles aprendessem, ensinassem e entrassem em equilíbrio. Acredito muito na figura do professor como um guia que mostra os diferentes caminhos possíveis aos seus alunos e eles escolhem qual querem seguir. Nestes casos, o equilíbrio acontece quando "os que não sabem nada", aprendem; e "os que sabem tudo" não ficam entediados.

\section{PALIMPSESTO}

10) Com o ensino remoto, houve uma espécie de invasão mútua de ambientes que antes eram privados, ou seja, os lares de alunos e de professores. Como administrar nossa interação quase obrigatória com o restante da família em casos em que o ensino remoto se mantiver?

\section{ADRIANA MARIA RAMOS OLIVEIRA}

Quase todas as plataformas (senão todas) têm um recurso chamado "alterar fundo" que permite que as pessoas te vejam, mas não vejam o ambiente que está atrás de você. Eu mesma já dei aulas estando na "Grécia", no "meu apartamento em Nova York" ou na "Biblioteca". Este recurso protege tanto a intimidade do professor quanto a dos alunos porque "esconde" o que está a tua volta: sejam móveis, objetos ou pessoas. Com isso, evitamos uma interação quase obrigatória com qualquer outro indivíduo que não seja o nosso aluno, a menos que ele/ela queira nos apresentar alguém ou algum animal de estimação, mas neste caso, não é uma interação forçada e sim uma escolha. 


\section{PALIMPSESTO}

11) Qual conselho você pode deixar para professores que ainda têm reservas quanto ao uso de tecnologias no ensino de Línguas?

\section{ADRIANA MARIA RAMOS OLIVEIRA}

Sei que o trabalho do professor envolve muitas mais horas do aquelas pelas quais somos pagos, mas aos professores que ainda têm reservas quanto ao uso de tecnologias no ensino de Línguas, só posso dizer - parafraseando Cazuza - que o tempo não para. E nós, como qualquer outro profissional, temos que evoluir também. As tecnologias vieram para ficar e não há como voltar, mas temos que pensar a tecnologia como algo muito mais amplo; não tem a ver com os aparelhos, as máquinas ou a internet que conhecemos hoje! A escrita nas cavernas era uma forma de tecnologia, a invenção do papel também e a criação da imprensa mais ainda. Essas tecnologias, em cada uma das suas épocas, nos permitiram chegar aonde estamos agora. E tenho certeza de que as de hoje nos permitirão chegar muito mais longe ainda. Cabe a nós fazer o que sempre fizemos na nossa profissão: pesquisar, estudar, nos aperfeiçoarmos para nos tornamos os professores que os nossos alunos precisam nos diferentes momentos da vida e fases de aprendizagem.

\section{Referências}

KOLB, David A. Experiential learning: Experience as the source of learning and development. Prentice Hall Inc., Englewood Cliffs: New Jersey, 1984.

MISHRA, P., y KOEHLER, M. J. Technological pedagogical content knowledge: A framework for integrating technology in teacher knowledge. Teachers College Record, 108 (6), pp. 1017-1054, 2006. 


\title{
Foreign Language Teaching in Digital Contexts: A New Learning Opportunity for Professors and Students
}

\author{
Adriana Maria Ramos Oliveira ${ }^{\mathrm{v}}$ \\ Interviewers: \\ Evânia Maria Ferreira do Nascimento ${ }^{\text {vi }}$ \\ Gabriela Ribeiro Nunes ${ }^{\text {vii }}$ \\ Marcela Santos Brigida viii \\ Translated By: \\ Gabriela Ribeiro Nunes \\ Marcela Santos Brigida
}

The year 2020 will be remembered by all those who survive it. This statement has a morbid tone to it, but one wonders how it could not be, when thousands have fallen victim to Covid-19. At the time of writing this piece, more than one hundred and seventy thousand people have died due to the disease in Brazil. Somehow, we will remember 2020 for a long time; either due to the proximity with which death has

\footnotetext{
v Professor Oliveira graduated in Literature (Portuguese-Spanish) at Universidade Federal do Rio de Janeiro (1996) and specialized as Professor of Lengua y Literaturas Españolas by the Agencia Española de Cooperación Internacional - AECI (1997) before earning her MA in Romance Languages at Universidade Federal do Rio de Janeiro (2000), and a magister in Alta Especialización en Filología Hispánica by the Consejo Superior de Investigaciones Científicas - CSIC (2002). She holds a PhD in Spanish Language and Applied Linguistics from UNED (2002) as well as a PhD in Language Studies from UFF (2019). She is a collaborating professor in the graduate courses at Estácio de Sá University, a professor at the Instituto Cervantes and a professor in Basic Technical and Technological Education at the Centro Federal de Educação Tecnológica Celso Suckow da Fonseca - CEFET/RJ in the Foreign Languages Applied to International Negotiations (LEANI) BA. She coordinates LEANI TRAD (Translation Laboratory of LEANI BA) and has experience in the area of Letras, with an emphasis on Spanish, Teacher Training, Translation and New Technologies Applied to Language Teaching.

vi Professor at Instituto Federal Fluminense, Santo Antônio de Pádua campus, and $\mathrm{PhD}$ student in Linguistics at UERJ.

${ }^{v i i} \mathrm{PhD}$ student in Literary Theory/Comparative Literature at UERJ.

viii PhD Student in Literary Studies at UERJ. CNPq Scholar.
} 
reached us through the loss of a relative or friend, or because of the new forms of being in the world that became necessary: the intensification of general hygiene, the use of a facial masks and the extremely painful physical social distancing, which crucially altered the routines of those involved in activities that involve crowds of people. And school activities are among those.

In compliance with measures to prevent the spread of the new Coronavirus, schools remained closed for a long time and, to try to continue teaching and learning processes, we submitted to remote teaching, in which the distance between teacher and student gives way to one of its main characteristics: the interaction (if any) is mediated by the use of new technologies. Now, student and teacher do not share the same space and time in the learning process.

In view of this new reality that we are facing as education professionals, we invite Professor Adriana Maria Ramos Oliveira to share her experiences and knowledge on the subject. Graduated in Letters (Portuguese-Spanish) from Universidade Federal do Rio de Janeiro (1996), she has a specialization as a professor of Lengua y Literaturas Españolas by the Agencia Española de Cooperación Internacional - AECI (1997), a master's degree in Neolatine Letters from the Universidade Federal do Rio de Janeiro (2000), magister in Alta Especialización en Filología Hispánica by the Consejo Superior de Investigaciones Científicas - CSIC (2002), PhD in Spanish and Applied Linguistics - UNED (2002) and PhD in Language Studies - UFF (2019). She is a collaborating professor in the Postgraduate courses at Universidade Estácio de Sá, Instituto Cervantes and Basic Technical and Technological Education at Centro Federal de Educação Tecnológica Celso Suckow - CEFET/RJ in the Foreign Languages Applied to International Negotiations (LEANI) Bachelor. Has experience in the area of Letters, with emphasis on Modern Foreign Languages (Spanish), Teacher Training, Translation and New Technologies Applied to Language Teaching.

We are very grateful for the acceptance of Professor Adriana, who showed us that the experience of distance language teaching mediated by digital tools, despite being a challenge for those who are not used to using them, does not compromise the quality of learning. On the contrary, they can make it even more enriching. The message she leaves us summarizes the teacher's work well. It is an invitation so that we do not let ourselves be discouraged and take advantage of the opportunities that this new 
paradigm has brought us, in order to become "the teachers that our students need at different times in life and learning phases". We were not prepared for this reality, but Professor Adriana showed us the importance of accepting challenges with all possible setbacks. Have a good reading, taking advantage of the knowledge that our interviewee kindly shared with Palimpsesto and our readers.

\section{PALIMPSESTO}

1) In the context of the teaching mediated by technologies in remote education, which has been propelled by the pandemic of the new Coronavirus, has it become easier to teach foreign languages? Is it possible to further expand the content and themes to be worked on or will it become even more difficult for the professor to select them?

\section{ADRIANA MARIA RAMOS OLIVEIRA}

Not necessarily. It will depend on the teacher because the technologies existed before the pandemic, but not all teachers used them. If we think that the teaching of a foreign language has always been reduced in schools and see technologies as a way to expand the physical space of the classroom, we can increase the number of hours that our students have in contact with the language. But I always say that the most important thing is to take to the classroom - physical or virtual - only the technology that will really help the teaching-work because it is useless to use technology that you are not used to and that involves an additional difficulty to the students. That is, in addition to learning the foreign language, they will also have to learn to deal with a tool that may be unknown to them just because the professor thinks they should use it, for example. In addition, we must not forget that "technology" is not only the modern devices we have or the internet. The cave paintings, the invention of paper or the creation of the press were technology in their own times as well.

\section{PALIMPSESTO}


2) With social isolation and remote education, many schools were forced to adopt digital platforms to move on with the school year. However, many professors, despite being inserted in a new context (a digital one), insist on teaching the subject practically in the same way as in person. As a researcher in the field, how do you think professors can fully incorporate digital tools in foreign language teaching? How can they use them in a face-to-face post-pandemic reality as well?

\section{ADRIANA MARIA RAMOS OLIVEIRA}

There needs to be extensive training in the digital area for professors to see technology in a broader way. It is not enough to make a Power Point presentation and to project it to say that you are incorporating a digital tool. For example, depending on the activity that we want to develop (as professors), we can use PowToon (https://www.powtoon.com) to offer instructions to students; we can create a work map with Canva (https://www.canva.com/); create a gallery of character avatars with Voki (https://www.voki.com/); give a series of clues for a mystery solving using Genially (https://app.genial.ly/); search for representative images on Pixabay (https://pixabay.com/es/), gamify content with Kahoot (https://kahoot.com/schools-u/) etc. Having in mind the possibility of expanding with new technologies the class time far beyond the physical space, nothing better than using the technology to our advantage and to develop our students' skills even remotely and with the benefit of greater inclusion and respect for the pace of each one, taking into account, mainly, that the most important thing is only to take the tools that help us in our teaching practice, for this not create a bigger problem for us as professors and for our students.

Even before the emergence of the pandemic, I already believed and defended that licentiate degree should include a course focused on new technologies for the development of digital literacy for future professors. In other words, that it was also possible to train new professors digitally so they could create materials, produce didactic videos, work with multimedia tools etc. in a more practical and simple way, because if before they taught us - in didactic classes - how to write on the board, where to position ourselves in the classroom, teaching methodologies... in this new reality, regardless of Covid-19, we need to train teachers with digital skills as well! 


\section{PALIMPSESTO}

3) Faced with an apparent conflict revealed in the speech of some schoolteachers who are reluctant to use new technologies, how can schools appropriate the new languages and forms of digital interaction in order to respect the subjectivities of students and teachers?

\section{ADRIANA MARIA RAMOS OLIVEIRA}

Whenever I meet a colleague who is reluctant to use new technologies, I remember how waiters took orders about ten years ago. If we think that they took orders on blocks of paper before and now take notes on tablets or interactive screens, what would happen to the waiter who told his boss "I will not learn this" or "I want to continue taking orders on paper", or even "I don't know how to use it"? They would probably be fired! That is, if all professions had to adapt to new technologies at some point, why would teachers be any different? Something that always caught my attention in relation to the classroom is that, despite the years that pass, it does not evolve properly. If we take a picture of one of the first cell phones and one from now, we will see that the changes are immense, but if we take a picture of a classroom from the 1950s and one from now, we will see that there are almost no differences.

Finally, I recommend an extremely useful book called Mão na massa ${ }^{2}$, in which the authors make a selection of a series of digital tools that can be incorporated into the foreign language classroom.

\section{PALIMPSESTO}

4) You are developing a project titled "Os blogs no ensino do espanhol como língua estrangeira: proposta de uma revista virtual" in which you show a concern with what has become known as digital literacy. What does this concept consist of, what is the importance of understanding it and where did your interest in that theme come from?

\section{ADRIANA MARIA RAMOS OLIVEIRA}

The purpose of this project is to work with the use of blogs as one of the many tools available on Web 2.0. Both students and professors need to adapt to the new 
educational models, and this implies a change, a new approach and new methods that bring us closer to the so-called "digital literacy". The proposal to create a digital magazine in a foreign language makes it so that the use of the blog is a tool for searching, processing, and producing relevant information for the students learning as a whole. The blog can provide that the digital literacy goal becomes closer because it is a tool that allows presenting content in a simple and attractive way for students. As the blog allows generating, publishing and exchanging content in multiple formats (video, image, audio) without the need for a great technological capacity and it relates to other formats and applications of the network such as web pages, social bookmarks, content generators etc., it becomes a suitable tool for the work carried out by the institution foreign language teachers, for other teachers in the public and/or private school network of the State of Rio de Janeiro and to encourage foreign language promotion activities among the institution's students, in particular, from the creation of the digital magazine. Therefore, this project had as its main goal to present the blog as a technological tool in the teaching of foreign languages. Spanish, in particular.

\section{PALIMPSESTO}

5) How can we work on our responsibilities as citizens when we present the world to our students in language classes through so many available digital tools?

\section{ADRIANA MARIA RAMOS OLIVEIRA}

As I have said, the most important thing, when we bring any technology to the classroom, is to take only what can facilitate the teaching work and, consequently, the teaching/learning process. Anything that represents an additional difficulty/problem should be avoided. Therefore, the teacher needs to make a selection and a kind of curatorship of the tools he intends to use, and he must be truly clear about the goals he intends to achieve with the use of the tool(s).

In addition, Mishra, and Koehler (2006, p. 1018) claim that just introducing technology to the teaching-learning process is not enough. Recently, questions about what teachers should know to incorporate technology properly in their practices have received a lot of attention. The focus of research is increasingly on how technology is 
used by teachers. For the authors, teachers nowadays will always have to update knowledge about the use of Information and Communication Technologies (ICT) and incorporate them into their practices.

\section{PALIMPSESTO}

6) In your opinion, how is it possible to overcome the barriers that the digital context imposes on the interaction between students when it comes to teaching foreign languages? Is the development of oral abilities affected?

\section{ADRIANA MARIA RAMOS OLIVEIRA}

In my opinion, the digital context does not impose any barriers on interaction with students! We continue to interact with them, but in a different way. When comparing face-to-face and digital interaction, we see that, in most cases, digital interaction is already the one that our students use most today. That is, they interact much more with each other, with family members, with teachers digitally than in person. It is true that our culture is much closer and more affectionate regarding the teacher-student relationship, especially when it comes to young children, but when we are talking about young people or adults, the vast majority is always posting opinions on social networks, writing messages in apps, liking content, etc.

Currently, the tools used for remote teaching (Microsoft Teams, Zoom, Google Meet, Skype etc.) allow synchronous teacher-student or student-student interaction. It is possible to form pairs, play, develop question and answer activities and any other activity that stimulates and develops orality. In addition, we can also record videos or audios to analyze the student's expression in more detail later and there are a number of other dynamics that were not possible in person and are only possible because we are in a digital context. Therefore, if the teachers research and learn the resources of the platform that they are using in their teaching practice, they can develop many activities and work the four skills digitally, even more broadly than if they were working in person. Especially because, if we think that technologies help us to expand the physical space of the classroom - we will not be limited to a forty or forty-five-minute class, for 
example - we will be able to use all these resources in our favor in support of the students' learning.

\section{PALIMPSESTO}

7) How can we reconcile the different degrees of social inequality present at schools (and also at universities) in the post-pandemic context and the new types of knowledge acquired/constructed by professors?

\section{ADRIANA MARIA RAMOS OLIVEIRA}

This question is exceedingly difficult because it goes beyond how far we can go as teachers. In other words, before the pandemic, we already dealt with the social inequality issue present in educational institutions in several ways: placing a student who did not have access to the material to do an exercise with whomever had; paying for photocopies with pocket money to distribute to all students; sending texts and activities by email or WhatsApp trying to democratize access as much as possible, but we know that in the post-pandemic context, the social inequality that was already very large in our country, will be even bigger... I would say that we will need to do a kind of "terrain recognition" when the pandemic passes, to meet our students again, to listen to them, to respect individual needs and, from the landscape we find, do what we always do: design strategies that allow us to take knowledge to all. The advantage is that, with the new types of knowledge acquired/constructed by the teachers, this pedagogical/methodological design will be much easier because one of the characteristics of the new technologies is to adapt to the learning moment and needs of each one.

David Kolb (1984) developed a theory about four learning styles, in which he states that "adults have different ways of learning" and that they depend on how they perceive and process reality. According to the author, we can be adapters, assimilators, divergent, and convergent; thus, information is not captured in the same way by everyone since some process it (action), while others reflect on what they read or observe (thought). So, in my opinion, the best way to reconcile the enormous social 
inequality we have is to make the material we are going to work in the classroom available in several possible ways: a video, a text, an e-book, an image, an audio...

\section{PALIMPSESTO}

8) How can we take advantage of the students' digital knowledge (usually many times bigger than that of teachers') in pedagogical activities?

\section{ADRIANA MARIA RAMOS OLIVEIRA}

Quite easily. The teacher needs to understand that the classroom, virtual or not, is a two-way street. In other words, the teacher as a holder of all knowledge and the student as an empty box that need to be filled no longer exist. I usually say that I learn a lot more from my students than they do from me. We need to see the teaching/learning process as an exchange of knowledge. So, in the same way that I teach my students to conjugate a certain verb in a foreign language, for example, they can teach me how to edit a video.

\section{PALIMPSESTO}

9) How to balance the opposition of some students to using digital platforms for remote education with the euphoria of others for their use in a context of heterogeneity of the public being served?

\section{ADRIANA MARIA RAMOS OLIVEIRA}

Honestly, I do not think there is much the teacher can do in this case. In my experience, whenever I have found myself in this situation, the resistance of a few students to the use of digital platforms was due to ignorance of the tool in question, lack of access to the internet, but never because they had developed a total aversion to that platform. So, at first, I tried to give the basic information so that the student could, at least start, get in touch with the platform, see that "it wouldn't bite" and then made small groups between reluctant and euphoric students so that between them they could learn, 
teach, and find balance. I strongly believe in the teacher figure as a guide that shows the different paths possible to their students so they can choose which one they want to follow. In these cases, the balance happens when "those who know nothing", learn; and "those who know everything" are not bored.

\section{PALIMPSESTO}

10) With remote education, there has been a kind of mutual invasion of environments that were previously private, that is, the homes of students and teachers. How to manage our almost mandatory interaction with the rest of the family in cases where remote education is maintained?

\section{ADRIANA MARIA RAMOS OLIVEIRA}

Almost all platforms (if not all) have a feature called "change background" that allows people to see you, but not to see the environment behind you. I have taught classes in "Greece", in "my apartment in New York" or in the "Library". This feature protects the privacy of both the teacher and students because it "hides" what is around you: the furniture, objects, or people. With this, we avoid an almost mandatory interaction with any other individual who is not our student, unless he/she wants to introduce us to someone or to a pet, but in this case, it is not a forced interaction but a choice.

\section{PALIMPSESTO}

11) What advice can you give to teachers who still have reservations about using technologies in language teaching?

\section{ADRIANA MARIA RAMOS OLIVEIRA}

I know that the work of a teacher involves many more hours than we are paid for, but to teachers who still have reservations about the use of technologies in language teaching, I can only say - to paraphrase Cazuza - that time does not stop. And we, like 
any other professional, must evolve as well. Technologies are here to stay and there is no going back, but we must think of technology as something much broader; it does not have to do with the devices, the machines, or the internet that we know today! The writing in the caves was a form of technology, the invention of paper as well and the creation of the press even more. Those technologies, each in their own times, have allowed us to get to where we are now. And I am sure that those of today will allow us to go even further. It is up to us to do what we have always done in our profession: to research, study, and improve ourselves to become the teachers that our students need at different times in life and phases of learning.

\section{Works Cited}

KOLB, David A. Experiential learning: Experience as the source of learning and development. Prentice Hall Inc., Englewood Cliffs: New Jersey, 1984.

MISHRA, P., y KOEHLER, M. J. Technological pedagogical content knowledge: A framework for integrating technology in teacher knowledge. Teachers College Record, 108 (6), pp. 1017-1054, 2006.

\footnotetext{
${ }^{1}$ Mão na massa [recurso eletrônico]: ferramentas digitais para aprender e ensinar I = Hands on: digital tools to learn and teach I / Ana Carolina Nascimento ... [et al.]. - 1. ed. - São Paulo: Parábola, 2019.

2 Mão na massa [recurso eletrônico]: ferramentas digitais para aprender e ensinar I = Hands on: digital tools to learn and teach I / Ana Carolina Nascimento ... [et al.]. - 1. ed. - São Paulo: Parábola, 2019.
} 